\title{
Development of Web-based Information System for Universitas Negeri Jakarta
}

\author{
Prasetyo Wibowo Yunanto ${ }^{1}$, Diat Nurhidayat', and Rimulyo Wicaksono ${ }^{2}$ \\ ${ }^{1}$ Informatics and Computer Engineering Education Studies Program, Electrical Engineering, \\ Faculty of Engineering, State University of Jakarta, Rawamangun, Indonesia \\ ${ }^{2}$ Electronics Engineering Education Studies Program, Electrical Engineering, Faculty of \\ Engineering, State University of Jakarta, Rawamangun, Indonesia
}

\section{Abstract}

This study aims to produce a web-based Universitas Negeri Jakarta alumni data information system that can be accessed anywhere. The development of the alumni information system website, UNJ, is an Object-oriented Programming (object-oriented) by using the Unified Modeling Language (UML) as a model. The research was conducted using the waterfall method where the research went through several stages, namely needs analysis, system planning, and system design. In this study, two

Corresponding Author: Prasetyo Wibowo Yunanto prasetyo.wy@unj.ac.id

Received: 11 January 2019 Accepted: 14 February 2019 Published: 25 March 2019

Publishing services provided by Knowledge E

(c) Prasetyo Wibowo Yunanto et al. This article is distributed under the terms of the Commons Attribution License, which permits unrestricted use and redistribution provided that the original author and source are credited.

Selection and Peer-review under the responsibility of the 3rd ICTVET 2018 Conference Committee.

\section{G OPEN ACCESS} testing phases were carried out, namely feasibility testing and usability testing where this test was carried out after the web was completed and tested using a questionnaire as a research instrument. The research questionnaire distributed consisted of 18 questions grouped into 5 usability variables. Based on data processing, the results were obtained from the 5 usability variables used in the questionnaire, it can be seen that for each aspect of usability the percentage values are above $80 \%$ (Learnability, Efficiency, Memorability, Errors, and Satisfaction).

Keywords: alumni data, Universitas Negeri Jakarta, web

\section{Introduction}

In the era of information technology today, the development of the technology and information world is very rapid. Circumstances like this cause the agency or company will need an accurate information, so it can be reached in various fields to make a decision that is very effective and efficient. This can be used as an information medium for data collection of students who have completed education.

Speaking of education, it will not be separated from the results achieved from teaching and learning activities between students and lecturers. The results of the teaching activities are usually marked by the graduation of students who take their respective studies commonly known as alumni. The alumni data collection process that is usually done manually is no longer an option, given the vast global world. Therefore the need for websites is needed to get fast and accurate information. 
The Universitas Negeri Jakarta (UNJ) has 8 faculties such as the Faculty of Educational Sciences, the Language and Arts Faculty, the Mathematics and Natural Sciences Faculty, the Faculty of Social Sciences, the Faculty of Engineering, the Faculty of Sports Science, the Faculty of Economics and the Postgraduate Program.

Considering the above, it is necessary to change the information dissemination system carried out by the agency to alumni, so that the storage of information to alumni is more complete and fast. If agencies and alumni need information about the campus world and job openings can quickly get through the website.

This happens when the institute seeks information about alumni data that has passed their education for years, agencies do not need to bother asking other alumni. This kind of event will not occur if information about alumni is more updated in the information system. Based on the above understandings, the author tries to raise these issues into a research study entitled "Development of Alumni Information Systems for Universitas Negeri Jakarta Based on Websites".

\section{Information System}

An information system is a system that consists of collection, input, data processing, storage, processing, control, and reporting so that information is reached from a decision to achieve the desired goals and objectives. With an information system, the community becomes easier to obtain information quickly. The development of information systems also grows faster and faster, along with the development of technology today, for example the internet.

The internet is a media that is more efficient and practical than other media such as brochures, pamphlets, newspapers, and other print media. The internet is a relationship between different local networks in an area, city, and even country, to connect multiple computers into a network group that can utilize the progress of communication media (telephone and satellite). The web is one of the internet services that is often used by organizations, educational institutions, and companies. Therefore the use of the web as a container of information systems is considered very useful to disseminate information to all alumni at the Universitas Negeri Jakarta.

\section{Research Methods}




\subsection{Methods}

The development of the alumni information system website, UNJ is Object Oriented Programming (object oriented) by using the Unified Modeling Language (UML) as a model. At the design stage to create an alumni website using the Waterfall Model Process method [1]. The following is a stage image in the waterfall method. Waterfall model process method can be seen in Figure 1.

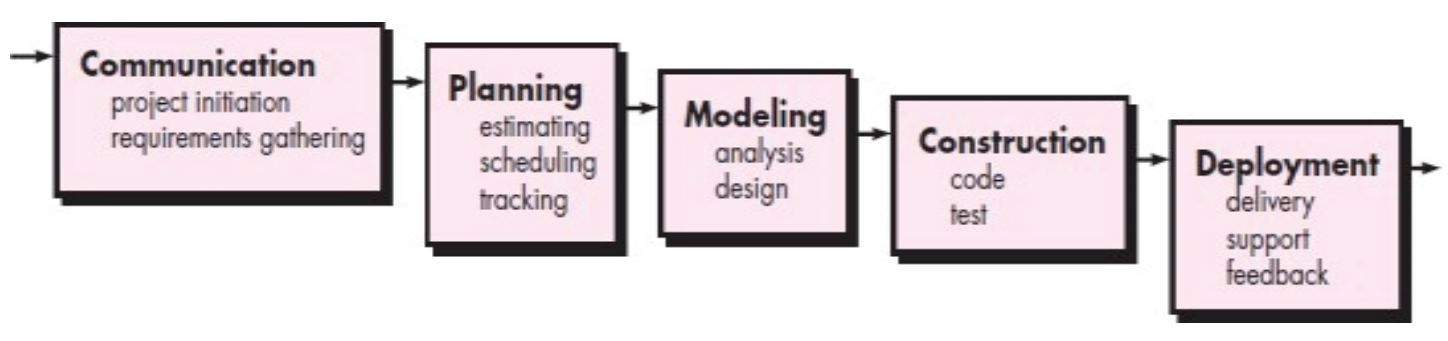

Figure 1: Waterfall Model.

\subsection{System development procedures}

The research procedure that will be carried out based on the Waterfall stages are:

\subsubsection{Need analysis}

The user needs to develop the alumni information system at UNJ are:

1. Facilitate the dissemination of information about alumni at the UNJ.

2. The UNJ alumni information system can be accessed via the internet.

3. Make it easy to find information about alumni at the UNJ.

\subsubsection{System planning}

This stage is the initial stage of making the alumni information system website. This modeling begins with looking for the needs of the entire system that will be applied in the form of software. This is very important, considering that software must be able to interact with other elements such as hardware, databases, etc. The purpose of system planning in creating websites includes:

1. Plan how the system specifications will be built. 
2. Software and hardware to be used.

3. The website that will be created has benefits for alumni.

4. How to design a system and database of a website.

\subsubsection{System design}

The design stage is the stage of translating the needs into a software representation, before the implementation of the program code begins. This study uses the UML in system design and software. UML is a set of diagrams that already have standards for describing object-oriented software designs. UML diagrams used are use case diagrams, activity diagrams and class diagrams [2].

\subsubsection{User interface design}

The database design process is an important step so that the system is developed efficiently in the use of storage space, data access, guaranteed data integration, and easy to manipulate. Before designing a database and programming applications, it is necessary to determine what data is needed and what will be generated by the system to be built. The following system is needed for the application of a website-based alumni information system.

1. User Administrator. Users are humans who are directly involved with application programs, namely administrators and alumni. The administration in question is related to user accessibility to the application system, such as Edit Password (for user login data), Edit Profile, and Role (specifying user status, as admin or normal user).

2. Admin Data. This data is the main admin who manages the UNJ Alumni website.

3. Alumni Data. This data consists of the main data of the Alumni Information System application, namely: alumni id, alumni name, date of birth, month of birth, year of birth, generation, status, photo of alumni, address of alumni, telephone, cellphone number, job, job address, gender, email, religion, and complete information data.

4. Information Data. ata is a collection of admin \& user status on the website. Information data are of two types, among others: job vacancy information data and news information data. 
5. Comment Data. This data is a collection of user and admin comments to the statuses contained on this website.

6. Message Data. This data is a collection of messages received or sent by the admin or alumni who are logged in.

7. Data Gallery. This data is a collection of photos or videos shared by the admin and user (alumni).

8. User. In the database user column there is user_id from the user and admin.

\subsection{Data analysis technique}

\subsubsection{System testing}

Programming is the activity of making a program or a series of instructions used to set the computer to work according to each instruction. Each program undergoes individual testing to ensure that the program is error free.

\section{Functional Testing [3]}

Feasibility testing of information systems will be tested by several examiners, including web makers, design experts and alumni of Informatics and Computer Engineering Education, Universitas Negeri Jakarta. Tests carried out alone using the Guttman scale [4].

2. Usability Testing [3]

Data collection is done by giving a set of statements written (questionnaire) to the respondent (student) to be answered. The statement used in the questionnaire uses a 5-point Likert scale [5], namely:

(a) Strongly Disagree (SD)

(b) Disagree (D)

(c) Neutral (N)

(d) Agree (A)

(e) Strongly Agree (SA)

The initial step of usability testing is to provide a number of tasks or tasks that have been prepared in advance for the user when interacting with the system being tested. This task was tested to 32 correspondents including those who were ptik 
alumni who had seen and tested the web system www.aptik-unj.com. This task is used as a means of interaction in usability measurement.

Each question from the questionnaire aims to show usability level according to user acceptance, which will be assessed in a value scale of 5 aspects in usability testing which includes five things, namely:

(a) Learnability (Lr). Explain the level of ease of users or users to complete basic tasks when they first see or deal with an existing system.

(b) Efficiency (Ef). Explain how fast users can complete tasks when they first learn the system.

(c) Memorability (Me). Explain the level of ease of the user or user in using the system properly, after a while not using it.

(d) Errors (Er). Explain the possibility of errors or errors made by users and how easily they can overcome them.

(e) Satisfaction (Sa). Explain the level of user satisfaction in using the system that has been created. The plot results of the five usability aspects above for 18 questionnaire questions. In this aspect, the scores will be given 1 - 5 for the satisfaction level of the correspondents and from the results of these values will be given an average value of each usability aspect. The questionnaire for measuring system usability is shown in Table 1.

\section{Research \& Testing Results}

\subsection{System planning}

The process of designing an alumni data collection information system uses UML diagrams. The UML diagrams used to design the Alumni Information System site in the Information and Computer Engineering Education Universitas Negeri Jakarta are use case diagrams, activity diagrams, and class diagrams. In this study the resulting product is a web-based alumni information system that will be used by 2 actors, namely admin and alumni.

\subsection{Testing results}


TABLE 1: The Questionnaire for Measuring System Usability.

\begin{tabular}{|c|c|c|c|c|c|c|}
\hline No. & Statements & SD & $\mathrm{D}$ & $\mathrm{N}$ & A & SA \\
\hline \multicolumn{7}{|c|}{ Learnability (Lr) } \\
\hline 1 & $\begin{array}{l}\text { You are understand the purpose of the } \\
\text { system being built }\end{array}$ & & & & & \\
\hline 2 & $\begin{array}{l}\text { This site have information that is objective, } \\
\text { valid, and supporting explanations }\end{array}$ & & & & & \\
\hline 3 & $\begin{array}{l}\text { You can quickly understand the functions } \\
\text { of the menus provided }\end{array}$ & & & & & \\
\hline 4 & $\begin{array}{l}\text { The menu on this site match what you } \\
\text { need? }\end{array}$ & & & & & \\
\hline \multicolumn{7}{|c|}{ Efficiency (Ef) } \\
\hline 5 & $\begin{array}{l}\text { The website can be accessed from the } \\
\text { external environment }\end{array}$ & & & & & \\
\hline 6 & $\begin{array}{l}\text { The writing style and language used in } \\
\text { accordance with the target user }\end{array}$ & & & & & \\
\hline 7 & $\begin{array}{l}\text { This site make it easy for you to find the } \\
\text { information you need }\end{array}$ & & & & & \\
\hline 8 & The way to use this site very simple & & & & & \\
\hline \multicolumn{7}{|c|}{ Memorable (Me) } \\
\hline 9 & This site provide up-to-date information & & & & & \\
\hline 10 & $\begin{array}{l}\text { This site provide complete and clear } \\
\text { information according to your needs }\end{array}$ & & & & & \\
\hline 11 & $\begin{array}{l}\text { This site make it easy for you to find the } \\
\text { information needed }\end{array}$ & & & & & \\
\hline \multicolumn{7}{|c|}{ Error (Er) } \\
\hline 12 & $\begin{array}{l}\text { There is a clear message about the error } \\
\text { link }\end{array}$ & & & & & \\
\hline 13 & $\begin{array}{l}\text { If an error occurs, this site provide a } \\
\text { notification message about the steps I } \\
\text { must take to resolve the problem }\end{array}$ & & & & & \\
\hline 14 & $\begin{array}{l}\text { You find when the clicked menu doesn't } \\
\text { respond }\end{array}$ & & & & & \\
\hline 15 & $\begin{array}{l}\text { Whenever you make a mistake, you can } \\
\text { return and recover quickly }\end{array}$ & & & & & \\
\hline \multicolumn{7}{|c|}{ Satisfaction (Sa) } \\
\hline 16 & $\begin{array}{l}\text { Overall, you are very satisfied with the } \\
\text { performance of this site }\end{array}$ & & & & & \\
\hline 17 & $\begin{array}{l}\text { This site provides all the features and } \\
\text { functions that you need }\end{array}$ & & & & & \\
\hline 18 & $\begin{array}{l}\text { Overall, you are satisfied with the ease of } \\
\text { use of this site }\end{array}$ & & & & & \\
\hline
\end{tabular}

\subsubsection{Functional testing results}

The total score of the functional test results is 40 (100\%). Of the total score, the functional- functional system that has been tested can be declared $100 \%$ feasible. 
Usability test is tested by assessing from the user's point of view, especially alumni of Universitas Negeri Jakarta. In this case the author takes a sample of 32 alumni respondents who have seen and tested the website www.aptik-unj.com.

From the results of questionnaire answers from 32 respondents then will be plotted with details of the multiplier values of each respondent's answer ( $S A=5 ; A=4 ; N=3$; $D=2 ; S D=1$ ) and the presentation value of each aspect of the answer and will be used likers scale method to see the usability ability of the web www.aptik-unj.com has been tested whether it has not been tested.

After being tested it is found to show the values of satisfaction or acceptance of each attribute. It can be seen that the percentage of each aspect is more than $80 \%$. This can mean that www.aptik- unj.com which has been made easily recognizable and applied by the user. If adjusted again, the relationship with each of usability Learnability aspects is 87.3\%, Efficiency 85.9\%, Memorable 85.4\%, Error 83.8\% and Satisfaction $86.5 \%$. It can be said that www.aptik-unj.com which has been created has Usability values, which are: Very good Learnability, Efficiency, Memorability, Errors, and Satisfaction (average presentation values above $80 \%$ ).

\section{Conclusions}

From a research result, the results of product development, test results, and product revisions as well as the discussions that have been described previously, can be drawn conclusions, including:

1. The development of the alumni website information system is carried out using the waterfall method with the stages of system analysis, system planning, system design, system design, system testing, system evaluation, and final products. The result of this development is a website-based agency information system product created using PHP and MySQL programming languages as data basics.

2. Based on website testing using functional testing and usability testing. The results show that the website Information System website at the UNJ is $100 \%$ feasible or functioning properly and shows the values of satisfaction or acceptance of each attribute with a percentage of each aspect over $80 \%$ (Learnability $87.3 \%$, Efficiency 85.9\%, Memorable 85.4\%, Error 83.8\% and Satisfaction 86.5\%), This can mean that the web system www.aptik-unj.com which has been made easily recognizable and applied by the user. 


\section{References}

[1] Roger S. Pressman, P. D. (2010). Rekayasa Perangkat Lunak: Pendekatan Praktisi. Yogyakarta: ANDI.

[2] Sri Dharwiyanti, Pengantar Unified Modeling Language (UML). Jakarta: IImu Komputer, 2013. Solichin, A. (2005). Pemrograman Web dengan PHP dan MySQL. Jakarta: Fakultas Teknologi Informasi, Universitas Budi Luhur.

[3] Nidhra, S. \& Dondeti, J. (2012). Black Box and White Box Testing Techniques- A Literature Review. International Journal of Embedded and Applications (IJESA) Vol. 2, No. 2.

[4] Sugiyono. (2013). Metode Penelitian Pendidikan Pendekatan Kuantitatif, Kualitatif dan R\&D. Bandung: Alfabeta Bandung.

[5] Saifudin Anwar. (2010). Metode Penelitian. Yogyakarta: Pustaka Belajar. 